\title{
Workplace hazard exposure and practice of safety measures by workers in selected factories in Nnewi, Anambra State, Nigeria
}

Okeke $\mathrm{JE}^{1}$, Osuchukwu $\mathrm{NC}^{1}$, Ndep $\mathrm{AO}^{1}$, Ekpenyong $\mathrm{BN}^{1}$ and $\mathrm{Abam}^{2} \mathrm{KI}^{2}$

${ }^{1}$ Department of Public Health, Faculty of Allied Medical Sciences, University of Calabar, Calabar, Nigeria

${ }^{2}$ Department of Biochemistry, Faculty of Basic Medical Sciences, University of Calabar, Calabar, Nigeria

Correspondence: Ndep AO. Email: drndep@gmail.com

\begin{abstract}
Background: Workplace safety measures are intended to reduce injuries, accidents and hazards to employees. This study was to determine the workplace hazard exposure, practice of safety measures and use of private protective equipment by workers in selected factories in Nnewi, Anambra State Nigeria.

Methods: Using a cross-sectional descriptive design, a semi-structured interviewer-administered questionnaire and an observational checklist were data collection tools. Using a stratified sampling and proportionate random sampling techniques 816 staff from three strata participated in the study.

Results: Out of the 634 completely filled questionnaires, 97.5\% respondents were males and $65.8 \%$ were aged 26-40years. Majority (78.6\%) had four or less years of experience and $23.5 \%$ earned between N21,000-N30,000 monthly. Most (96.8\%) were trained to use protective equipment and $93.7 \%$ believed that their current job was hazardous. Out of the 182 respondents with high level of workplace hazard exposure, 64.3\% were aged 26-30 years. Most respondents (92.6\%) reported having at least one job-related injury within the past year while 49.7\% felt that they may lose their job due to work-related injury. There was a statistically significant relationship between workplace hazard exposure and level of practice of safety measure $(p<0.005)$ and level of personal protective equipment use $(p<0.001)$.

Conclusion: Age and length of service at the factory had significant influence on the level of hazard exposure, level of safety practice and level of personal protective equipment use. In-service trainings and incentives for consistent practice of safety measures and PPE use could lead to lower accidents.
\end{abstract}

Key words: Workplace, hazards, safety, exposure, personal protective equipment

\section{Introduction}

Workplaces occupy a prominent place in national economy giving its importance for employment, productivity, exports, favourable balance of trade/payments and overall economic growth. A large number of people spend close to $70 \%$ of their entire life where they work which to a great extent affect their actions, abilities, performance and overall progress in life. ${ }^{1}$ However, due to work designs, mechanization processes and activities, work environment has proven hazardous and stressful which in modern day 
parlance is referred to as "occupational health hazard. ${ }^{2}$ Occupational hazard is defined as "an occurrence arising out of or in the course of work which results in fatal occupational injury or non-fatal occupational injury. ${ }^{3}$ Poor health status has been traced to exposure to these hazards, which constitute major determinants for employee's productivity. Workplace hazards are some of the major sources of complaints and disability amongst the labour force. ${ }^{3}$

Although most occupations are not without hazards, evidence however indicate that work associated injuries are extremely common among factory workers. $^{3-6}$ Employees of production factories are exposed daily to hazards in activities associated with production such as harvesting, transportation, storage and mixing. Despite the fact that management and employees make effort to ensure awareness and practice related to safety; accidents in the workplace especially in factories never abate indicating that most work environments especially in factories are still unsafe. Studies have shown lack of adequate safety education, health promotion interventions, lack of protective measures for factory staff and above all poor adherence of factory workers to health instructions regarding their safety in the workplace. ${ }^{7,8}$ In 2015, Nigeria lost three million jobs because of work infrastructure damage alluded to personday losses because of work disruption, strikes on the part of aggrieved workers and compensations to victims, estimated at N4 trillion annually. ${ }^{9}$ The Nigerian Factories Act of 1990 and subsequent revisions in 2004 is the only legislation for the enforcement of health and safety standards in Nigerian factories. ${ }^{10,11}$ This study was to determine workplace hazard exposure, level of use of Personal Protective Equipment (PPE) and level of practice of safety measures by factory workers in selected factories in Nnewi North Local Government Area of Anambra State Nigeria.

\section{Methods}

Nnewi is located in South-western part of Anambra State. It constitutes the second largest city in the state after Onitsha which has one of the largest markets in Africa with an estimated population of 391,227 from the 2006 National census figures. ${ }^{12} \mathrm{~A}$ cross-sectional descriptive study design was used. There are thirteen medium and large-scale manufacturing factories in Nnewi North Local Government Area each having 500 and above workers. A simple random sampling technique of nonreplacement by balloting was used to select six factories studied. Obtaining a sampling frame of 6,892 workers a minimum sample size of 364 was determined using appropriate formula. ${ }^{13}$ The minimum sample size was doubled and further increased by $12 \%$ to make for non-response bringing the total sample size to 816. A stratified sampling technique was adopted in segmenting the respondents into three major strata viz. management, line managers/supervisors and operational staff. All the twelve management staff (two per selected factory) were purposively selected, while 55 line managers and 749 operational staff were selected by proportionate sampling using their ranks in the overall population of staff, which was $7 \%$ and $93 \%$ respectively.

A semi structured intervieweradministered questionnaire in addition to a checklist was used in collecting data on work-related exposure to workplace hazards, availability of safety standards, practice of safety measures and use of PPE in the various factories. The questionnaire was developed with guidance from the 
constructs of the Health Belief Model and the researchers adopted the Health and Safety inspection checklist used by inspection officials in the Anambra State Ministry of Environment. The questionnaire was pre-tested using a testretest reliability method in two factories in a neighbouring Local Government Area among 41 factory workers (5\% of sample size). The questionnaire was administered twice, three weeks apart, to the same group of respondents. Data from the test and retest were analysed and a Cronbach's coefficient alpha was used to determine the internal reliability of the instrument. The Cronbach's alpha was 0.7 and the research team considered the instrument reliable. Assessment of individual item contribution to the Cronbach alpha revealed that all items appeared to have contributed to the overall Cronbach's alpha of 0.7 therefore no item was removed.

The data from the questionnaire were analysed using Microsoft Excel 2007 and Statistical Packages for the Social Sciences (SPSS). ${ }^{14,15}$ Mean value for the continuous variables was used as cut off points to determine levels of knowledge. Respondents with knowledge values below the mean score were categorized 'low knowledge' those with mean score 'moderate' and those with scores above the mean 'high knowledge'. Test of statistical significance was considered at $p<0.05$ for 95\% confidence interval. Simple descriptive statistics and frequencies were used to describe the data generated from the observation checklist. Ethical approval was obtained from Anambra State Ministry of Health and permission to conduct the study was secured from the Management Board of the participating factories while respondents gave verbal informed consent after providing them enough information about the study. The field assistants were undergraduate students who were trained on data collection.

\section{Results}

Out of the 816 questionnaires administered 634 were found complete for analysis giving a response rate of $77.6 \%$. This is still well above the calculated minimum sample size of 364 . Almost all $(97.5 \%)$ the respondents were males and those aged 2630 years had the highest proportion of respondents $(33.9 \%)$ while $60.1 \%$ were married and $71.9 \%$ had secondary education. Majority (78.6\%) of the respondents had at least four years experience on their job and $46.1 \%$ have had 3-4 years of working experience. As for length of service within the factories $37.9 \%$ have been working in the factory for 3-4 years and $44.6 \%$ earned below N30,000 monthly. The monthly minimum income reported was N21,000 (Table 1). Most respondents said they were exposed to dust $(93.2 \%)$, noise $(93.2 \%)$, heat $(81.2 \%)$ and $97 \%$ were exposed to shocks and gas inhalations. More than half of the respondents $(68.1 \%)$ had moderate hazard exposure levels while $28.7 \%$ had high hazard exposure levels in their current jobs. Out of the 182 respondents with high level of workplace hazard exposure, $64.3 \%$ were aged $26-30$ years which is the youngest age group in the study.

Most (92.6\%) of the respondents reported to have had at least one job-related injury within the past year and $74.8 \%$ said they were absent from work due to job-related injury during the same period. Majority $(95 \%)$ of the respondents believed that they were likely to develop a job-related health issue at some point during their career. Respondent's socio-demographic characteristics and level of adherence to the Health and Safety Act of 1990 (HAS1990) showed a statistically significant relationship, $(p<0.001)$. There was also a 
significant relationship between length of service with the factory, monthly income and adherence to HSA-1990 $(\mathrm{p}<0.001)$. (Table 2).

On adherence to Health and Safety Act of 1990 (HAS-1990) at the work place, only $41.6 \%$ from $26-30$ years age group had high level of adherence while those aged
$31-40$ years had $45.5 \%$ high adherence level (Table 3). There was a statistically significant relationship between workplace hazard exposure and level of safety practice $(p=0.004)$, level of PPE use $(p<0.001)$ and level of adherence to the Health and Safety Act of 1990 (HAS1990) $(\mathrm{p}=0.006)$.

Table 1: Respondent's socio-demographic characteristics and level of adherence to (1990) Safety Act standards $(n=634)$

\begin{tabular}{|c|c|c|c|c|c|}
\hline \multirow[b]{2}{*}{ Variables } & \multicolumn{3}{|c|}{$\begin{array}{l}\text { Level of adherence to (1990) Safety } \\
\text { Act standards }\end{array}$} & \multirow[b]{2}{*}{ Test* } & \multirow[b]{2}{*}{ p-value } \\
\hline & $\begin{array}{l}\text { Low } \\
\text { Freq. (\%) }\end{array}$ & $\begin{array}{c}\text { Act standar } \\
\text { Moderate } \\
\text { Freq. (\%) }\end{array}$ & $\begin{array}{l}\text { High } \\
\text { Freq.(\%) }\end{array}$ & & \\
\hline \multicolumn{6}{|l|}{$\overline{\text { Age (years) }}$} \\
\hline $21-30$ & $90(42)$ & $35(16.4)$ & $89(41.6)$ & 21.000 & $<0.001$ \\
\hline $31-40$ & $66(35.3)$ & $36(19.3)$ & $85(45.5)$ & & \\
\hline$>40$ & $53(22.7)$ & $43(18.5)$ & $137(58.8)$ & & \\
\hline \multicolumn{6}{|l|}{ Educational Qualification } \\
\hline Primary & $35(22.6)$ & $30(19.4)$ & $90(58)$ & 12.951 & 0.012 \\
\hline Secondary & $169(37.1)$ & $80(17.5)$ & $207(45.4)$ & & \\
\hline Tertiary & $5(21.7)$ & $4(17.4)$ & $14(60.9)$ & & \\
\hline \multicolumn{6}{|l|}{ Working experience (years) } \\
\hline$<1$ & $15(32.6)$ & $4(8.7)$ & $27(58.7)$ & 9.726 & 0.137 \\
\hline $1-2$ & $76(36.9)$ & $41(19.9)$ & $89(43.2)$ & & \\
\hline $3-4$ & $87(29.8)$ & $49(16.8)$ & $156(53.4)$ & & \\
\hline$>5$ & $31(34.4)$ & $20(22.2)$ & $39(43.3)$ & & \\
\hline \multicolumn{6}{|l|}{ Length of stay wit $h$ firm (years) } \\
\hline$<1$ & $16(32.0)$ & $4(8.0)$ & $30(60.0)$ & 24.629 & $<0.001$ \\
\hline $1-2$ & $127(40.4)$ & $59(18.8)$ & $128(40.8)$ & & \\
\hline $3-4$ & $56(23.3)$ & $45(18.8)$ & $139(57.9)$ & & \\
\hline 5 and above & $10(33.3)$ & $6(20.0)$ & $14(46.7)$ & & \\
\hline \multicolumn{6}{|l|}{ Monthly income (Naira) } \\
\hline $30,999.00$ and below & $118(41.7)$ & $50(17.7)$ & $115(40.6)$ & 20.609 & $<0.001$ \\
\hline $31,000.00-40,999.00$ & $35(30.0)$ & $19(16.2)$ & $63(53.8)$ & & \\
\hline $41,000.00$ and above & $56(24.0)$ & $45(19.2)$ & $133(56.8)$ & & \\
\hline
\end{tabular}

Significant at $\mathrm{p}<0.05$ at $95 \%$ confidence interval

*Pearson's Chi Square 
Table 2: Socio-demographic characteristics and level of hazard exposure $\quad(n=634)$

\begin{tabular}{|c|c|c|c|c|c|}
\hline \multirow[b]{2}{*}{ Variables } & \multicolumn{3}{|c|}{ Level of hazard exposure } & \multirow[b]{2}{*}{ Test* } & \multirow[b]{2}{*}{ p-value } \\
\hline & $\begin{array}{l}\text { Low } \\
\text { Freq.(\%) }\end{array}$ & $\begin{array}{l}\text { Moderate } \\
\text { Freq.(\%) }\end{array}$ & $\begin{array}{l}\text { High } \\
\text { Freq.(\%) }\end{array}$ & & \\
\hline \multicolumn{6}{|l|}{ Age (years) } \\
\hline $21-30$ & $12(5.6)$ & $86(40.2)$ & $116(54.2)$ & 169.123 & $<0.001$ \\
\hline $31-40$ & $5(2.7)$ & $120(64.2)$ & $62(33.1)$ & & \\
\hline$>40$ & $3(1.3)$ & $226(97.0)$ & $4(1.7)$ & & \\
\hline
\end{tabular}

Marital status

$\begin{array}{lrrrrr}\text { Single } & 12(5.9) & 81(39.5) & 112(54.6) & 116.973 & <0.001 \\ \text { Married } & 8(2.1) & 307(80.6) & 66(17.3) & & \\ \text { Divorced } & 0(0.0) & 30(90.9) & 3(9.1) & & \\ \text { Widowed } & 0(0.0) & 14(93.3) & 1(6.7) & \end{array}$

Educational Qualification

$\begin{array}{lrcccc}\text { Primary } & 3(2.0) & 148(95.5) & 4(2.5) & 90.724 & <0.001 \\ \text { Secondary } & 17(3.7) & 261(57.2) & 178(39.0) & & \\ \text { Tertiary } & 0(0.0) & 23(100) & 0(0.0) & & \end{array}$

Working experience (years)

$\begin{array}{lrrrrr}<1 & 5(10.9) & 15(32.6) & 26(56.5) & 76.749 & <0.001 \\ 1-2 & 6(2.9) & 124(60.2) & 76(36.9) & & \\ 3-4 & 6(2.0) & 244(83.6) & 42(14.4) & & \\ 5 \text { and above } & 3(3.3) & 49(54.4) & 38(42.2) & & \end{array}$

Length of service with current factory (years)

$\begin{array}{lrrrrr}<1 & 5(10.0) & 16(32.0) & 29(58.0) & 137.564 & <0.001 \\ 1-2 & 12(3.8) & 167(53.2) & 135(43.0) & & \\ 3-4 & 3(1.1) & 249(92.2) & 18(6.7) & & \end{array}$

Monthly income (Naira)

\begin{tabular}{lrrcrr}
$30,999.00$ and below & $16(5.7)$ & $126(44.5)$ & $141(49.8)$ & 166.696 & $<0.001$ \\
$31,000.00-40,999.00$ & $2(1.7)$ & $78(66.7)$ & $37(31.6)$ & & \\
$41,000.00$ and above & $2(0.9)$ & $228(97.4)$ & $4(1.7)$ & & \\
\hline
\end{tabular}

Significant at $p<0.05$ at $95 \%$ confidence interval

*Pearson's Chi Square 
Table 3: Comparison of respondent's level of adherence to (1990) Safety Act standards, safety practices, PPE use with level of hazard exposure $(n=634)$

\begin{tabular}{|c|c|c|c|c|c|}
\hline \multirow[b]{2}{*}{ Variables } & \multicolumn{3}{|c|}{ Level of hazard exposure } & \multirow[b]{2}{*}{ Test* } & \multirow[b]{2}{*}{ p-value } \\
\hline & $\begin{array}{l}\text { Low } \\
\text { Freq.(\%) }\end{array}$ & $\begin{array}{l}\text { Moderate } \\
\text { Freq. }(\%)\end{array}$ & $\begin{array}{l}\text { High } \\
\text { Freq.(\%) }\end{array}$ & & \\
\hline \multicolumn{6}{|l|}{$\begin{array}{l}\text { Level of adherence to } \\
\text { (1990) Safety Act }\end{array}$} \\
\hline Low & $11(5.3)$ & $154(73.7)$ & $44(21.0)$ & & \\
\hline Moderate & $3(2.6)$ & $68(59.6)$ & $43(37.7)$ & 14.549 & 0.006 \\
\hline High & $6(2.0)$ & $210(67.5)$ & $95(30.5)$ & & \\
\hline \multicolumn{6}{|c|}{ Level of safety practices } \\
\hline Low & $8(3.3)$ & $180(75.0)$ & $52(21.7)$ & & \\
\hline Moderate & $9(3.4)$ & $100(38.3)$ & $152(58.2)$ & 15.258 & 0.004 \\
\hline High & $3(1.3)$ & $152(65.0)$ & $79(33.8)$ & & \\
\hline \multicolumn{6}{|l|}{ Level of PPE use } \\
\hline Low & $20(5.0)$ & $367(92.2)$ & $11(2.8)$ & 364.771 & 0.001 \\
\hline Moderate & $0(0.0)$ & $43(37.7)$ & $71(62.3)$ & & \\
\hline High & $0(0.0)$ & $22(18.0)$ & $100(82.0)$ & & \\
\hline
\end{tabular}

Signific ant at $\mathrm{p}<0.05$ at $95 \%$ confidence interval

*Pearson's Chi Square

\section{Discussion}

For self-reported health issues among factory workers $46.4 \%$ of our study population reported having injuries from machines out of which $8.8 \%$ fell from heights and $20 \%$ had chest injuries. These are similar to findings of a study that assessed occupational issues among artisans and factory workers based in Ifo, Nigeria where their job hazards were disorders in muscles, bones, joints, skins and respiratory organs. ${ }^{15}$ On awareness of poor health due to exposure to a workrelated hazard, findings in this study were similar to a study aimed at determining the awareness of occupational hazards amongst factory workers in a Nigerian sawmill, where respiratory tract infections were commonly reported. ${ }^{8}$ In this study, majority of respondents with moderate levels of exposure to hazards (that is, routine exposure to five or six out of a possible 11 hazardous activities) had low levels of use of PPEs.

Majority of those within the N41,000N50,000 monthly income bracket had low levels of use of their PPEs. Usually in workplaces, the higher the income level, the more likely the person has more experience on the job, more education and holds some kind of leadership position. Therefore, these results suggest some level of complacency among this category of workers. In a study to investigate the level of compliance of 10 staff of the Federal Ministry of Labour and Productivity, Inspectorate Division, who were the custodians of Occupational Safety and Health (OSH) the workers failed to comply with some OSH regulations, which were their duty to enforce. Only $20.3 \%$ of the respondents reported provision of PPEs by employers. ${ }^{16}$ This is similar to a study of an Indian chemical factory where researchers discovered that injured workers were given treatment in health centre belonging to the factories they however are not provided with safety kits during their job functions. However, it is in contrast with this study where workers reported having PPEs but the use varied by age and work experience. In a study on the awareness of occupational hazards and utilization of 
safety measures among welders in Kano Metropolis Nigeria, age, nature of training, exposure, educational attainment and worker's experience were found as major determinants of workplace safety practices. ${ }^{16}$

With respect to awareness of occupational hazards, findings from this study are similar to a study carried out among sawmill and cement factory workers in north-central states in Nigeria. ${ }^{8,11}$ Less than $20 \%$ of the respondents used protective gadgets during their work activities and safety policies and regulations were neither practiced nor enforced. ${ }^{17}$ In a study in Kano Metropolis Nigeria, researchers found age, nature of training, exposure, educational attainment and workers experience as major determinants of workplace safety practices, which are similar to findings in this study. ${ }^{1}$

\section{Conclusion}

Age and length of service at the factory had significant influence on the level of exposure to workplace hazard, level of safety practice, level of PPE use as well as adherence to the HSE-1990. Therefore, the researchers recommend the following that in addition to training on safety, hazard exposure and PPE use at point of e m p lo y m e n t, p e e r - t o - p e e r communications on adherence to safety measures should be encouraged. Visible signs placed at strategic locations throughout the factory could act as 'cues to action' for safety practices at work. More experienced staff could act as mentors to younger and less experienced colleagues to create a culture of safety at the work place.

\section{Acknowledgements}

The authors will like to thank Dr. Edem Akpan, Prof. A. Adindu, Dr. S. N. Olaniran and other staff of the Department of Public
Health who contributed to the conceptualization of this research. Special thanks to Late Dr. U. Zacchaeus for his contribution and encouragement that led to the completion of this work. May his gently soul rest in peace.

\section{References}

1. Saidu IA, Utti VA, Jaiyesii AO, Maduagwu SM, Onuwe HA, Jajere AM. Prevalence of musculoskeletal injuries among factory workers in Kano Metropolis, Nigeria. International Journal of Occupational Safety and Ergonomics. 2012;1(17):99-102.

2. Kalejaiye PO. Occupational health and safety: Issues, challenges and compensation in Nigeria. Peak Journal of Public Health and Management. 2013;1(2):16-23.

3. Bankole AR, Ibrahim LO. Perceived influence of health education on occupational health of factory workers in Lagos state, Nigeria. British Journal of Arts and Social Sciences. 2012;8(1):57-65.

4. Ahmed HO, Abdullah A. Dust exposure and respiratory symptoms among cement factory workers in the United Arab Emirates. Industrial Health. 2012;50:214-22.

5. Aderaw Z, Engdaw D, Tadesse T. Determinants of occupational Injury: A Case Control Study among Textile Factory Workers in Amhara Regional State, Ethiopia. Journal of Tropical Medicine. 2011:1-8.

6. Omotosho M, Bamidele J, Salaudeen A, Saromi H, Omi AA. Occupational hazard awareness and safety practices among cement factoryworkers at Obajana, Kogi state, Nigeria. Elixir Bio Diversity. 2012;47:9013-8.

7. Awoyemi AO. An assessment of 
health facilities and environmental conditions in some Nigerian stone quarries. Savanna Medical Journal. 2001;4:19-21.

8. Feremi FA, Ogunfowokan AA, Mbada C, Olatubi MI, Ogungbemi AV. Occupational hazard awareness and safety practices among nigerian sawmill workers. International Journal of Medical Science and Public Health. 2014;3(10):1244-8.

9. NBS. Work infrastructure damage and job loss. Abuja, Nigeria:

National Bureau of Statisitics, 2014.

10. Dodo M. The Application of Health and Safety Plan in Nigerian Construction Firms. Jordan Journal of Civil Engineering. 2014;8(1):817.

11. Onohwosafe SP. Provision of healthcare services as correlates of incidence of occupational diseases among cement factory workers in Ogun State, Nigeria. Ozean Journal of Social Science. 2014;7(1):19-26.

12. NPC. [Nigeria] and ICF International. Nigeria Demographic and Health Survey, 2013. Abuja,
Nigeria and Rockville, Maryland, USA: 2014; National Population Commission and ICF International.

13. Krejcie RV, Morgan DW.

Determining sample size for research activities. Educational and Psychological Measurement. 1970;30:607-10.

14. IBM-SPSS. Statistical Packages for the Social Sciences. 20 ed2015.

15. Microsoft. Microsoft Excel. Microsoft; 2007.

16. Oranusi US, Dahunsi SO, Idowu SA. Assessment of occupational diseases among artisans and factory workers in Ifo, Nigeria. Journal of Scientific Research \& Reports. 2014;3(2):294-305.

17. Umeokafor N, Umeadi B, Keith KJ, editors. Compliance with occupational safety and health regulations: a review of Nigeria's construction industry. 3rd International Conference on Infrastructure Development in Africa; 2014 17th - 19th March; Abeokuta, Nigeria. 